\title{
Video game localization: the case of Brazil
}

\author{
Ricardo Vinicius Ferraz de Souza*
}

\begin{abstract}
When the first video games appeared back in the 1950's, they presented themselves as a technology with great potential and a bright future. What not many people expected is that, nearly half a century later, video games would become a multibillion dollar industry, rivaling other important industries of the entertainment world such as the film and the music industries in terms of revenue and popularity. With the growing expansion of the sector, combined with the necessity of making their games global, many developers and publishers are increasingly investing in translation and localization. This paper gives an overview on the relation between video games and translation at different stages of the development and evolution of the industry. It also addresses, through the analyses of a number of games, the different stages of video game localization in Brazil, with its particularities and idiosyncrasies. The analysis is based on the concept of "gameplay experience" by Mangiron and O'Hagan, in addition to making use of other principles presented by Bernal Merino, Scholand and Dietz. It also focuses on the historical development of video games in Brazil and the way translation is utilized and displayed on the screen from the perspective of a video game player.
\end{abstract}

Keywords: Video Games; translation; localization; video game localization in Brazil.

Resumo: Quando os primeiros videogames apareceram na década de 1950, eles se apresentaram como uma tecnologia de grande potencial e com um futuro promissor. o que muitos não esperavam é que, cerca de meio século depois, o videogame se tornaria uma indústria multibilionária, rivalizando com outras indústrias importantes do mundo do entretenimento em termos de faturamento e popularidade, tais como as indústrias do cinema e da música. Com a crescente expansão do setor, aliada à necessidade de internacionalizar seus jogos, muitas desenvolvedoras e editoras estão

\footnotetext{
"Master's degree student in Translation Studies at the University of São Paulo (USP), Brazil. Email: ricardovinicius_souza@hotmail.com.
} 
investindo cada vez mais em tradução e localização. Este artigo visou traçar um panorama acerca da relação entre videogames e tradução ao longo dos diferentes estágios de desenvolvimento e evolução da indústria e também abordou, por meio da análise de alguns jogos, os diferentes estágios da localização de jogos no Brasil, com todas as suas particularidades e idiossincrasias. A análise se baseou no conceito de “experiência de jogabilidade" de Mangiron e O’Hagan, além de fazer uso de outros princípios apresentados por Bernal Merino, Scholand e Dietz; também focou o desenvolvimento histórico dos videogames no Brasil e a maneira como a tradução é utilizada e exibida na tela sob o ponto de vista de um jogador de videogames.

Palavras-chave: Videogames; tradução; localização; localização de jogos no Brasil. 
Souza, R. V. F. - Video game localization: the case of Brazil

\section{Introduction}

"After the end of World War II, the world was split into two - East and West. This marked the beginning of the era called the Cold War."

The sentence above, taken from the game Metal Gear Solid 3: Snake Eater (Konami, 2004), accurately portrays the international context of most of the second half of the twentieth century. After the end of the Second World War in 1945, the world witnessed the rise of two superpowers which would exert a huge influence in the postwar world: the United States and the Soviet Union. Due to their enormous political, economic, and especially military power, they divided the world into two political systems (capitalism and communism) and split it into zones of influence, often giving other countries little choice but to align themselves to one of the superpowers. On account of the existing antagonism between capitalism and communism, the relations between both blocs were usually conflictive, but always treated with extreme caution. In fact, the Cold War was marked by a constant state of fear, as a result of the mutual concern that a single "misstep" could lead to a nuclear war between the USA and the USSR, which, in practical terms, could mean the total annihilation of the world. For this reason, most of their clashes were waged in the political and strategic spheres: while attempting to attract more countries to their sphere of influence, the USA and the USSR were conducting research so as to develop new technologies that could help them not only to enhance their weapons (giving them a bigger and more devastating firepower), but also to enable them to predict or anticipate the opponent's possible next moves, providing them time to outline the best strategy for a more effective response. And it was precisely this technology which eventually gave birth to an industry that would forever change the entertainment world: video games.

In 1958, during the preparations for the annual visitor's day at Brookhaven National Laboratory, the American scientist William A. 
Souza, R. V. F. - Video game localization: the case of Brazil

Higinbotham was thinking of alternatives of how to make the visits to Brookhaven more pleasant for the public. After thoroughly examining the instruction manual for one of the analog computers, he realized that the very same technology used to calculate and simulate the trajectory of missiles or bullets could also be utilized to create some sort of interactive game, capable of entertaining the public during the visit (LAMBERT 2008; NowAK 2008). With the help of the engineer Robert Dvorak, Higinbotham managed to project on the oscilloscope an interactive experience which simulated a tennis game with a lateral perspective, and which allowed players to control the movement of the ball through two control boxes connected to the analog computer (LAMBERT 2008; NowAK 2008). On October 18, Higinbotham introduced the public to Tennis For Two, which is considered by many as the first video game in history ${ }^{2}$ (LAMBERT 2008; NowAK 2008). Four years later, in 1962, Steve Russell and his staff at the Massachusetts Institute of Technology presented Spacewar!, a game which simulated a battle between two spaceships while traveling in outer space. Unlike Tennis For Two, Spacewar! was far beyond a mere pastime for visitors to a laboratory. Actually, Spacewar! was a revolutionary game inasmuch as, in addition to demonstrating the potential of the video game technology (Bernal Merino 2006), it would introduce and establish some of the canons which can still be observed in modern video gaming (BARTON \& LOGUIDICE 2009b). Nonetheless, video games would have to wait for a decade to leave the laboratories and reach the masses. Pong (ATARI 1972) is commonly seen as the first game to be directed to a broader audience. The game had a concept which combined simplicity and fun, and its commands were easy to learn, which meant that everyone was able to play it without major complications. Thus, with a formula intended to make the player's task as easy as possible, Pong soon

\footnotetext{
${ }^{2}$ The question regarding which is the first video game in history is quite controversial. Notwithstanding, although there are claims that other games came before Tennis For Two, it is commonly believed that "Higinbotham's design was the first to feature moving graphics, or video, and incorporate what would become the three essentials of a video game: a computer connected to a graphical display and handheld controller" (NowAK 2008).
} 
Souza, R. V. F. - Video game localization: the case of Brazil

became a resounding success, which is why the game is usually considered to be that which turned video games from a laboratory experience into a promising industry (Discovery CHANnel 2007). In the following years, although Pong's formula was exhaustively copied, some developers were working on new ideas which could help them perfect it. In this regard, games like Space Invaders (TAITO 1978), Pac-Man (NAMCO 1980), and Donkey Kong (NINTENDO 1981) were of fundamental importance, not only to help to place Japan at the forefront of the video game industry (along with the United States), but especially to move away from the prevailing paradigm at the time and introduce innovative ideas. By introducing charismatic characters, more interesting narrative elements, and more compelling soundtracks and effects, these games planted the seeds that would contribute decisively to shaping video games as we know them today. The result of this process can be better observed in Super Mario Bros. (NINTENDo 1985). The charismatic Mario (from Donkey Kong) was back to save the princess; but this time, in a totally different way. As a matter of fact, the player was introduced to an innovative style of game to which he/she was not accustomed to up until then. The player was no longer confined to a fixed screen, and could now explore the environment by advancing from the left to the right of the screen, with the world being unveiled as he/she progressed (Discovery Channel 2007). The physiognomy of the characters also improved and seemed more convincing than in previous years. And the scenery and enemies were more diversified, providing a more challenging, varied and fun game experience, turning the "simple" task of saving the princess into an epic journey, full of dangers and adventures. All this, enriched by a striking soundtrack, made Super Mario Bros. a huge success worldwide, and contributed to make Nintendo into the leading company on the video game market. From then on, it was noticed that the concept of simplicity popularized by Pong no longer sufficed to make a game attractive; it was necessary to combine technological evolution with a good story and a more balanced level of difficulty. This perception was accentuated during the late 1980 's and early 1990's, when Nintendo began to 
Souza, R. V. F. - Video game localization: the case of Brazil

have the competition of Sega in an intense dispute for the hegemony of the video game market. On account of the fierce competition, both companies were obliged to search for alternatives to make their products more interesting, which caused the quality of their games to rise considerably. However, video games were still seen as "children's stuff" and many did not take them seriously. But that would change in 1994, when an "intruder" in the dispute between Sega and Nintendo would take the decisive step to lead the industry to a new level. After all, the technological and conceptual innovations introduced by Sony Playstation allowed a much more mature approach. With more storage capacity provided by CDs (in comparison to the traditional cartridges) and the possibility of inserting more realistic graphics, the games became more sophisticated and compelling. Narratives became much richer and denser, approximating them even more to those seen in the movies or in the literature. Games like Resident Evil (CAPCOM 1996), Final Fantasy VII (SQUARE 1997) and Metal Gear Solid (Konaml 1998) are considered true masterpieces, among other reasons, for dealing with the narrative from a much more adult and profound perspective, causing the bond between the player and the game to be no longer just visual, but also emotional. Thus, it can be said that it was in the Playstation era that video games reached their point of maturity, when they were finally able to break away from the label of "children's toy" to become established as a serious and professional industry. Nowadays, video games are one of the most powerful and profitable industries in the entertainment world. It is also one of the fastest growing worldwide: with the increase in the number of platforms available and with a wide range of games of the most varied kinds, genres and levels of complexity, video games have gained an increasingly larger and more diverse consumer audience. Estimates project that the video game industry sales might reach an annual growth rate of 18.7 percent, with a potential global revenue of US\$ 64.9 billion by 2013 (UOL JOGOS 2010). By maintaining this pace, video games have what it takes to become consolidated not only as a 
Souza, R. V. F. - Video game localization: the case of Brazil

global and multibillion industry but also as one of the leading forms of entertainment in the twenty-first century.

\section{The History of Video Game Localization}

In the first decade of the existence of video games, the role played by video game localization was practically null. This is probably due to the technological limitations of the time. During these years, the technology, although promising, was still in its infancy, which frustrated any attempt to develop something more complex. For this reason, the games often presented very simple mechanics and somewhat rustic graphics. The scarcity of in-game linguistic content also caused video game localization to be put on the backburner; for developers, their primary concern was to invest their time, effort and money in improving the technology. Yet this scenario began to change from the mid-1980's. Encouraged by the success of Super Mario Bros. and the positive impact that it had on the sales of the Nintendo Entertainment System (NES), many Japanese companies saw in the video game localization a chance to expand their business into other markets, especially that of North America. With an increasing amount of in-game linguistic content, a good number of the games to be released thereafter would be available in a Japanese version, aimed at the local audience, and a localized English version, destined for the North American and international audience. But not all was a bed of roses: this time it was the localization process which proved too primitive. Many companies used non-native translators, whose knowledge both of English and of translation techniques and theory was quite limited. Some translations were so "unique" that they ended up becoming hilarious. This was the birth of Engrish, the name whereby this "process of localization" is known today, and which immortalized sentences like "Congraturation. This story is happy end. Thank you" (Ghosts 'n 
Souza, R. V. F. - Video game localization: the case of Brazil

Goblins, CAPCOM 1986) or "A winner is you" (Pro Wrestling, NINTENDO 1986). This kind of practice gradually ended, especially during the transition from the 8bit to the 16-bit era in the early 1990's. The industry began to have a wider perception of the importance of video game localization, which consequently improved the quality of the translations (ACTIVE GAMING MEDIA 2010). This period also marked the end of "bilingualism" in the consoles: many games, in particular those with a bigger popular appeal and/or sales potential, began to receive versions in other languages (Active Gaming MEDIA 2010). That was the case of the Sega Genesis/Mega Drive version of Fifa International Soccer (ELECTRONIC ARTS 1993), which offered the option of playing the game in English, French, German or Spanish. Nonetheless, the turning point for video game localization would only come in the mid-1990's (BERNAL MERINO 2006): as the games became more complex and presented new features (such as oral dialogues), the players became far more demanding, obliging companies to offer not only technological improvements, but also linguistic ones. Thus, if developers and publishers wanted to make their games global, they would have to provide an impeccable localization service. Nowadays, video game localization has become a very professional service, with a very strict process of quality control. The concept of "localization" goes far beyond a mere linguistic transfer; it involves a series of other variables like history, culture, customs, linguistic and numerical conventions (SCHOLAND 2002), in short, all the local specificities that make a determined geographical region unique in relation to others. This notion can be better understood by examining the images below:
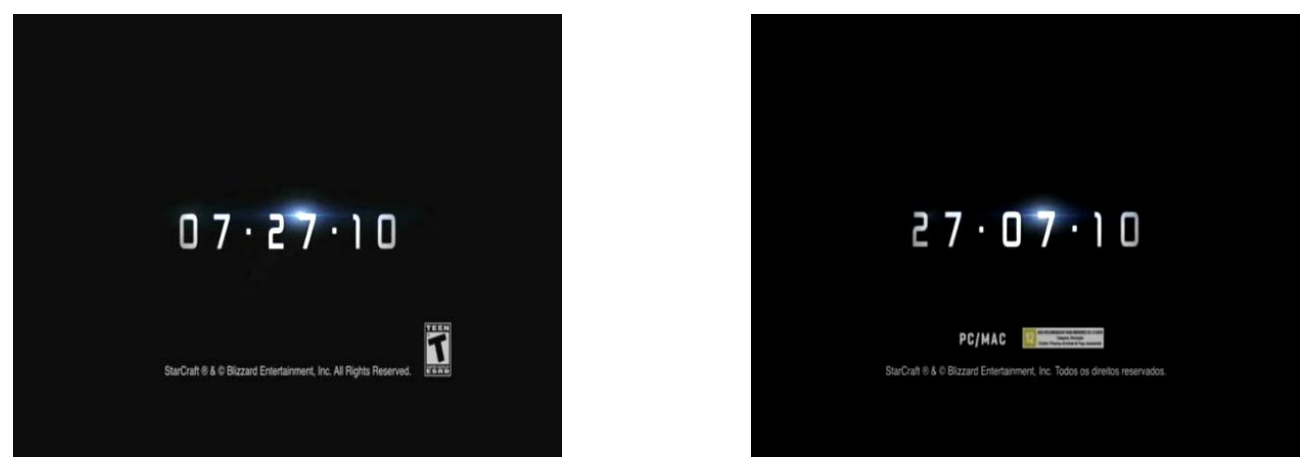
Souza, R. V. F. - Video game localization: the case of Brazil

$\begin{array}{lc}\text { Image 1: Starcraft II: Wings of Liberty } & \begin{array}{c}\text { Image 2: Starcraft II: Wings } \\ \text { of Liberty }\end{array} \\ \text { TV commercial (United States). } & \text { TV commercial (Brazil). }\end{array}$

These are images from the TV commercials of Starcraft II: Wings of Liberty (BLIZZARD 2010) in both the American and Brazilian versions. At first glance, one aspect already stands out: date conventions. In this case, the date needed to be adapted from the convention used in American English $(\mathrm{mm} / \mathrm{dd} / \mathrm{yy})$ to that utilized in Brazilian Portuguese $(\mathrm{dd} / \mathrm{mm} / \mathrm{yy})$. Another element of localization found in the images is the presence of the respective regulatory bodies: the symbol of the American body $E S R B^{3}$ was replaced by the Brazilian body $D J C T Q^{4}$, along with their respective age ratings for both North American and Brazilian audiences. Finally, the linguistic content was also localized, with the excerpt All Rights Reserved being translated by its equivalent in Portuguese Todos os direitos reservados.

Another key point for a successful localization resides in what Mangiron and O’Hagan call "gameplay experience":

The main priority of game localisation is to preserve the gameplay experience for the target players, keeping the 'look and feel' of the original. The brief of the localiser is to produce a version that will allow the players to experience the game as if it were originally developed in their own language and to provide enjoyment equivalent to that felt by the players of the original version (MANGIRON \& O'HAGAN 2006).

As seen above, the translator's main goal is to grant gameplay experience, which causes his/her job to be of fundamental importance for the success of the localized version. A poor translation might simply ruin gameplay experience by diverting the player's main focus from the game to the translation. A good example of this can be seen in Call of Duty: Modern

\footnotetext{
${ }^{3}$ Entertainment Software Rating Board.

${ }^{4}$ Departamento de Justiça, Classificação, Títulos e Qualificação (Department of Justice, Rating, Titles and Qualification).
} 
Souza, R. V. F. - Video game localization: the case of Brazil

Warfare 2 (ACTIVISION/INFINITY WARD 2009) and its respective localization into Japanese. One of the missions in the game is called No Russian, wherein the leader of a terrorist group orders his subordinates not to speak Russian. During the Japanese localization, the sentence was mistranslated as Kill them; They are Russian (UOL JOGOS 2009). Obviously, Japanese players were very unhappy about it, with many claiming they would rather buy the original English version or not buy it at all. Therefore, translators must be extremely careful, because they are not just translating a language; they are translating experience (O'HAGAN 2007).

As for the linguistic content, there are also a number of aspects to consider when localizing a video game. First, translators must know about the different types of video game genres, insofar as each one of them requires a different approach. An RPG cannot be translated the same way as an action game, as each has its own characteristics, idiosyncrasies, and consequently, its own kind of language. It is also important to be familiar with each game's genre terminology and conventions, which may range from literary language to more technical and specific terms (DIETz 2007). A different approach is also required when translating the various kinds of linguistic contents present in a game. Due to the extensive material to be translated and their distinct purposes (Bernal Merino 2007), different kinds of textual genres must be applied in the translation: while the dubbing, for example, must serve as a faithful reproduction of the speech, the User Interface requires a clear and concise language. One final aspect refers to a very common characteristic of video game localization: space constraints. As there is a strict limit on the number of characters to be used, translators must choose words very carefully, not only to respect space constraints but also to convey and preserve the idea of the original. In this regard, translators must be very creative in order to successfully capture the same message from the original, and, at the same time, not exceed the permitted number of characters.

But most of all, translators must be fully aware of their target audience. In this regard, Essential Facts About The Computer and Video Game 
Souza, R. V. F. - Video game localization: the case of Brazil

Industry shows some interesting facts about the gamers' profile. With reference to their average age, it shows a very different result from what many people usually think: 53 percent of the players are in the 18-49 age group, whereas a significant 29 percent belongs to the 50+ years; the "children's age group", namely, that under 18 years old, accounts for only 18 percent of gamers (ESA $2011: 2$ ). Therefore, translators must always bear in mind that video game localization is an adult service aimed at an adult audience, and mistakes like those seen during the Engrish era are no longer accepted or tolerated.

\section{Video Game Localization in Brazil}

Although the first games to offer localized content date from the $1980{ }^{\prime} s^{6}$, the golden age for video game localization in Brazil is undoubtedly the early 1990's. As seen previously, there was fierce competition between Sega and Nintendo, both seeking to expand their business around the world. In search for markets unexplored by the rival Nintendo (SUZUKI 2009), Sega signed a partnership with Brazilian company Tec Toy so as to have its products commercialized in Brazil. Thus, Sega Master System was officially released in Brazil in 1989 and was an instant success. This popularity was only possible thanks to the strategy Tec Toy adopted: besides distributing the games officially in Brazil, some games came into Brazilian Portuguese in fully localized versions. Because it is an extremely fruitful period for video game localization in Brazil, let us examine some of the localized games that were officially distributed at that time:

\footnotetext{
${ }^{5}$ Entertainment Software Association.

${ }^{6}$ When Odyssey 2 was released in Brazil, Phillips decided to commercialize the games with their respective titles in Portuguese. Because linguistic content was practically non-existent, the localization process basically consisted of translating the titles, boxes, manuals and, in certain cases, the characters.
} 
Souza, R. V. F. - Video game localization: the case of Brazil

\section{$\odot$ Phantasy Star (SEGA 1987)}

Sega's RPG Phantasy Star, released in Brazil in 1991, is of special importance to video game localization in Brazil as it was one of the first console games to be localized into Brazilian Portuguese, which is why many players say that it was the first game they ever had. As can be inferred, translation played a key role in the game's success. Moreover, because RPGs were still not widely known to the Brazilian audience, the translation, in addition to being a decisive factor for many players to buy the game, also helped boost and consolidate RPGs as a genre that should be taken seriously and which, just like the other genres, could very well provide fun. Finally, as one of the first games to be localized into Brazilian Portuguese, Phantasy Star gained attention from the media, and the extensive marketing campaign adopted by Tec Toy helped popularize the game.

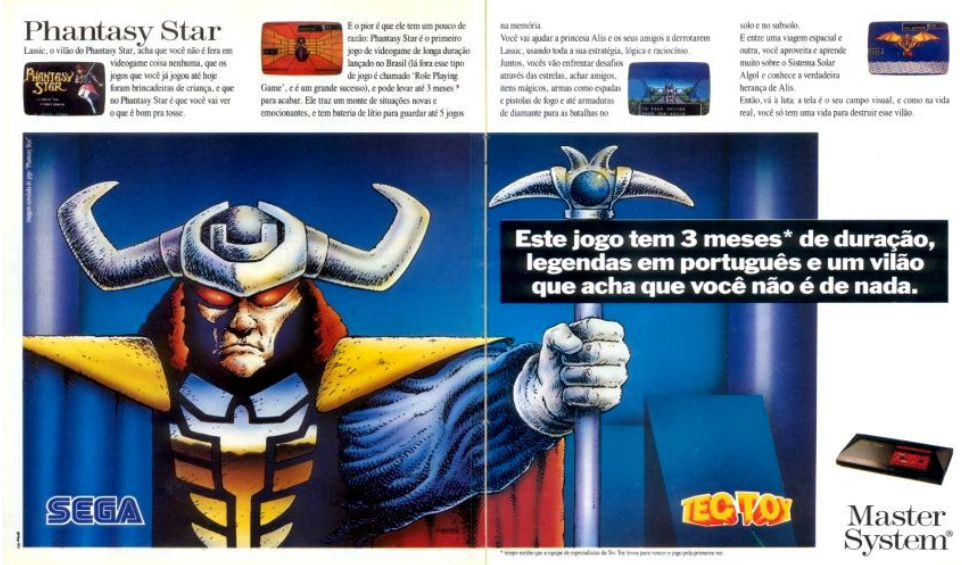

Image 3: Tec Toy's Advertisement for Phantasy Star. (Source:http://gazetadealgol.com.br/_media/diversos/scans/scanps1_propaganda.jpg)

The advertisement above shows that Tec Toy's strategy to popularize the game was exactly to explore the language and the genre issues. The message in the black box on the right makes it clear: 
Souza, R. V. F. - Video game localization: the case of Brazil

This game lasts for three months, has subtitles in Portuguese and a villain who thinks you are nothing.

The message tries to emphasize that the player is before something completely different to everything he/she has ever seen. First, it emphasizes the duration of the game: RPGs are commonly longer than games from other genres. Consequently, the player will not come across something that he/she may play for a week and then simply put it away; he/she will be entertained for at least three months. Then, the message appeals to something even stronger: the game has subtitles in Portuguese. This is enough to arouse the player's interest in buying the game for a simple reason: most games released in Brazil at the time came in other languages (especially English). Now, he/she has the opportunity to fully understand and enjoy a game, since the reality of the game has been brought within his/her reach. Games are no longer "outsiders"; now, the game and the player "speak the same language".

The localization of Phantasy Star was indeed a great achievement; but it also represented a great challenge for the people involved in the localization process, requiring a good deal of effort and creativity by the translators ("Gagá" Rов 2009: 27). In effect, the challenges had already begun when localizing the game from Japanese into English. The process of localization for the western market had to go through certain adaptations, which had certain implications for the names of some characters. Due to technical limitations, the names of the protagonists could not exceed four characters ("Gagá" Rов 2009: 19); for this reason, Arisa (アリサ), Tairon (タイロン) and Rutsu (ルツ) became Alis, Odin and Noah respectively. The only one to keep its original name intact was Myau (ミヤウ). One of the antagonists' names has a quite curious particularity: Dāku Farusu (ダークファルス) is apparently an allusion to the English term Dark Force. The 
Souza, R. V. F. - Video game localization: the case of Brazil

problem is that one of the possible translations of the word Farusu (ファルス)

is Phallus, which, for most people, is not an appropriate name. Luckily, the name Dark Phallus exceeded the eight character-limit for antagonists' names, and was renamed as Dark Falz ("GAGÁ" Rов 2009: 19).

The localization of the Portuguese version was probably based on the English version. Hence, the names of the protagonists, antagonists, other enemies and locations were unchanged ${ }^{7}$. On the other hand, the items, weapons, and magic spells were translated and/or adapted to the appropriate context. But what most drew the attention of the Brazilian audience was the translation of the menus and especially the dialogues, which was of great help for the complete understanding of the plot. Let us now go over some of the strategies used during Phantasy Star's localization process.

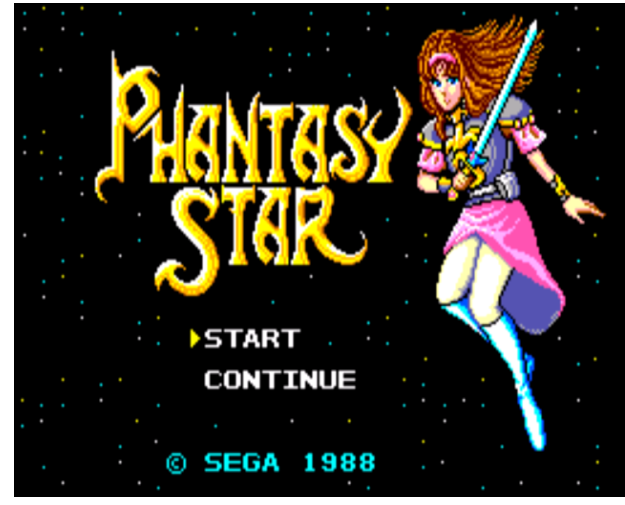

Image 4: Phantasy Star's start menu

(English version).

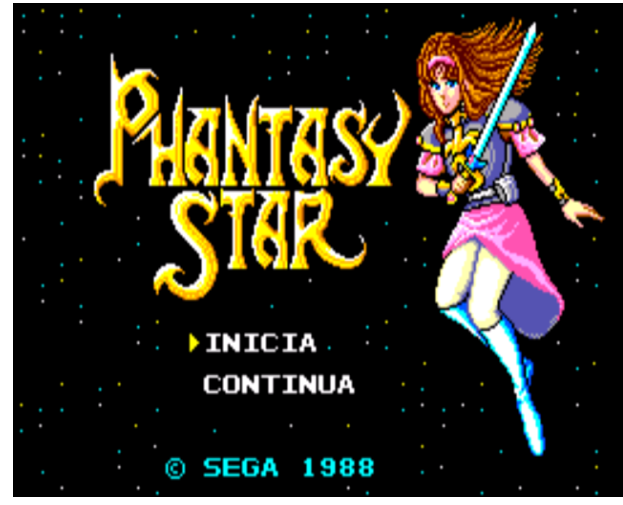

Image 5: Phantasy Star's start menu

(Portuguese version).

These are Phantasy Star's start menus from both English and Portuguese versions. The first traces of the difficulties faced by the translators can already be seen here. The commands Start and Continue were translated as Inicia and Continua respectively. If analyzed by modern standards and by the way menus are usually translated into Portuguese, the verbs should be in their infinitive forms Iniciar and Continuar. Probably due to

\footnotetext{
${ }^{7}$ One exception is the planet Dezoris, which was changed by the shortened form Dezóri.
} 
Souza, R. V. F. - Video game localization: the case of Brazil

space constraints, this was not an option. Another possibility could be to translate Start as Início. But this was not feasible for two reasons: the first is the absence of certain accented letters from the Portuguese language (as will be seen in the next paragraph), such as í. This could cause some confusion, since the presence or absence of the acute accent above the I would change the meaning and the pronunciation of the word: Início [i'nisju] is a noun whose equivalents in English are Start/Beginning, whereas Inicio [ini'siw] is the first person singular in the present tense which means I start// begin; and the second is that the conversion of Start into the noun Inicio would imply in the conversion of Continue into the noun Continuação ("Continuation" in English), which would cause the word to have three extra characters. For this reason, the decision to translate Start and Continue as Inicia and Continua (both in their imperative forms) seemed fortunate, given that the original idea was successfully preserved.

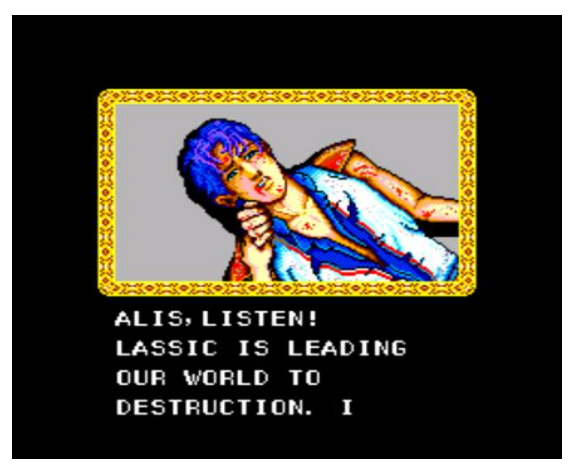

Image 6: Fragment from Phantasy Star's Intro (English version).

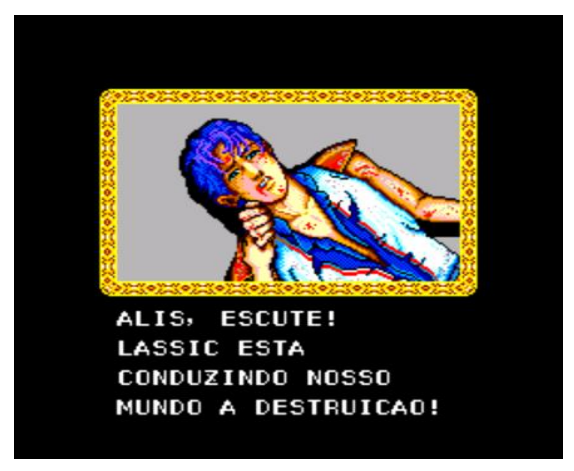

Image 7: Fragment from Phantasy Star's Intro (Portuguese version).

Translation is not the problem here; on the contrary, the sentence is clear and the original idea was accurately reproduced. What the images show us is another common challenge faced by Phantasy Star's translators and by translators in general during those years: the absence of accented letters from the Portuguese language. As the game was probably localized based in the English version, the translators must have been limited to use only the 
Souza, R. V. F. - Video game localization: the case of Brazil

existing characters in the English language. As a result, characters which are non-existent in English, as is the case of Ç (c-cedilla) or accented vowels, could not be used. It did not harm the full comprehension of the sentence as the context helped to elucidate any possible ambiguities. But in a different context, this could have caused problems, as twelve accented letters are

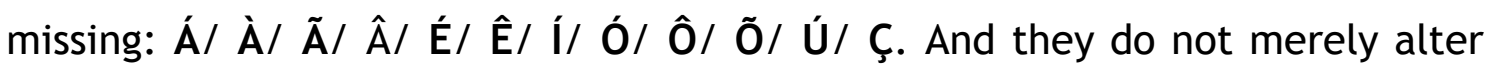
pronunciation; in some cases, they may change the meaning of the word. Take the word Esta as an example: as well as Início and Inicio, the presence or not of the accent is determinant. In the sentence above, the correct would be Está $\left[\mathrm{es}^{\prime} \mathrm{ta}^{8}\right]$, which is the equivalent of is in Portuguese. Without the acute accent, the word becomes Esta ['esta'], whose translation would be this. Thus, if not contextualized, the excerpt Lassic está conduzindo ("Lassic is leading") would turn into Lassic esta conduzindo ("Lassic this leading"), which is an ungrammatical construction. The expression a destruicao also highlights the absence of three other important characters: $\grave{A}, \tilde{A}$ and Ç. With reference to the latter two, the difference is that of sound. The character $\tilde{A}$ represents a variant sound of the letter $\mathbf{A}$, whereas $\mathbf{A}$ denotes an oral realization which leads to the phoneme /a/ (except preceding nasalized consonants like $m$ or $n$ ), while $\tilde{A}$ indicates a nasalized sound, represented by the phoneme /ê/. C and Ç also represent two different phonemes: / $/ \mathrm{k} /$ (preceding $a, o$ and $u$ ) and /s/ (preceding the same previous vowels) respectively. Therefore, by the way it is written above, the word destruição [destruj'sẽw10], becomes destruicao [destruj'kaw], realization not found in any variant of Portuguese. On the other hand, the character $\grave{A}$ represents an orthographic difference in relation to $\mathbf{A}$, as they are both pronounced / $/$ / (although sometimes À might be pronounced as a long vowel and $\mathbf{A}$ as a short one). This happens because the character $\mathbf{A}$ may refer both to an article and a preposition. In the former case, A refers to the feminine definite article, whose equivalent in English is the; as for the

\footnotetext{
${ }^{8}$ Other possible realizations of the word "Está" were not considered.

${ }^{9}$ Other possible realizations of the word "Esta" were not considered.

${ }^{10}$ Other possible realizations of the word "Destruição" were not considered.
} 
Souza, R. V. F. - Video game localization: the case of Brazil

latter, A denotes a preposition which indicates "direction in space" (MICHAELIS, 1998-2007), having in the preposition to its main equivalent in English. When both article and preposition need to be used in the same sentence, they merge into $\grave{A}$, in order to avoid repetition. This way, the term a destruição can only be used if it merely refers to the destruction; if intended to reproduce the idea to (the) destruction, the correct form would be $\underline{a}$ destruição. Thus, the correct form of the sentence would be (including the missing characters):

Alis, escute! Lassic está conduzindo nosso mundo à destruição!

Although these hurdles may have made the translators' job more difficult, they were able to convey the necessary game experience to offer the player a high degree of entertainment. Actually, Phantasy Star was a pioneer in Brazil, as it opened a whole new range of opportunities for video game localization in the country.

\section{○ Mônica no Castelo do Dragão (TEC ToY 1991)}

While Phantasy Star was basically a "translation", Mônica no Castelo do Dragão ("Monica in the Dragon's Castle") contained more elements of localization. Released in 1991, the game was adapted from Wonder Boy in Monster Land (SEGA 1988). Although aspects like graphics and gameplay were kept intact, much of the game was changed. Initially, the protagonist was changed: a neutral Wonder Boy was replaced by Mônica, a very popular and charismatic Brazilian comic character. This decision was responsible for creating a higher level of identification between the player and the game, given that a cultural element that everyone was familiar with was added to the plot. The protagonist's main weapon was also modified not only to adapt to the Brazilian audience, but also to be coherent with the comics. As anyone who reads her stories probably knows, Mônica has an inseparable friend: 
Souza, R. V. F. - Video game localization: the case of Brazil

Sansão ("Sansom"), her blue stuffed bunny, which she uses not only as a toy, but also as a way to punish some of her friends, who often torment her. Consequently, the decision to replace Wonder Boy's swords (his main weapons) by Sansão was natural. Another interesting fact concerns the antagonist. In Wonder Boy in Monster Land, the main antagonist is a dragon named Meka, while in Mônica no Castelo do Dragão, the same dragon is renamed to Cospe-Fogo ("Spitfire"). However, he is no longer the main villain, but a powerful ally of the new antagonist, Capitão Feio ("Captain Ugly"), a very well-known character in Mônica's comic stories. Even though Capitão Feio is presented as the main antagonist, he does not appear in the game, being just mentioned as the evil mind behind the plot. All of Mônica's enemies (even Cospe-Fogo) act on Capitão Feio's behalf.

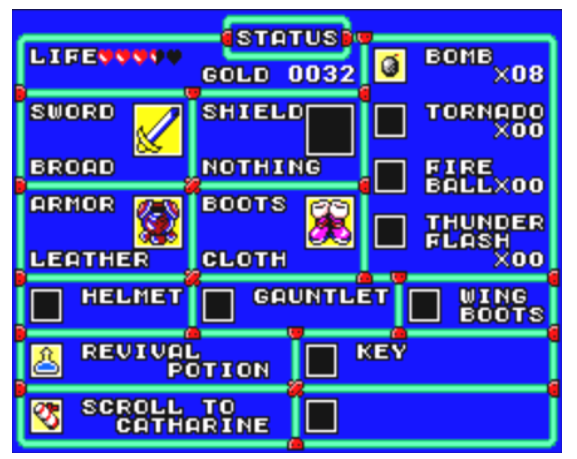

Image 8: Wonder Boy in Monster Land's

Status Screen.

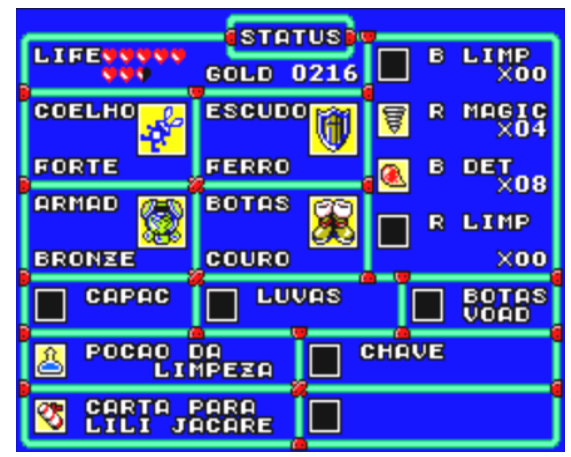

Image 9: Mônica no Castelo do Dragão's

Status Screen.

These are the status screens, which show some of the collectible items the player can obtain throughout the game, the character's health (represented by the word Life) and the amount of money earned (represented by the word Gold). The latter two were not translated and were kept as it is in the original. The decision not to translate the word Gold was possibly based on usage, given that its respective translation Ouro has the same number of characters. The most used and appropriate word for the case in question would be Moeda ("Coin"), used in its plural form Moedas. But it would 
Souza, R. V. F. - Video game localization: the case of Brazil

probably stumble on space constraints: Moedas would exceed Gold by two characters, which, as seen above, was not possible. And because Gold was not translated, the word Life was not translated either. Although Vida, its equivalent in Portuguese, has the same number of characters, it might have caused some misunderstandings, since Vida admits two different interpretations: it may refer to the character's health (as is the case) or to the number of lives the character is entitled. In regard to the remaining items, there are certain aspects that should be mentioned. As discussed previously, the weapons were altered to suit the Brazilian audience. As a result, a slight change was also necessary on the status screen to make it consistent with the changes made. Throughout the game, Wonder Boy has to defeat numerous enemies, including the bosses (the dragon's henchmen) in order to advance to the next stage. This also grants him the opportunity to upgrade his equipment and get stronger weapons. As the weapon changes, it is displayed on the status screen. As for Mônica, her main weapon is a stuffed bunny (Sansão), which will follow her during the entire journey, even when she defeats the bosses and "gains" Wonder Boy's swords. The solution for this problem was to apply a level of strength (Fraco/ Médio/ Forte/ Super/ Hiper - Weak/ Average/ Strong/ Super/ Hyper, respectively) to the bunny every time Mônica defeats a boss and receives a sword. When this takes place, the bunny's level of strength increases, allowing Mônica to inflict greater damage on her enemies. As for the other items, as the character advances in the game, he/she will face stronger enemies, and, if not well equipped, the chances of failing are considerable. To solve this problem, the player can visit the various shops spread around the game to buy items, which are basically four: armor, shields, boots and magic spells. Each one contributes to strengthen the character and increase his/her "firepower". As for the translation, some items were translated literally, but most were changed to fit Mônica's stories. 
Souza, R. V. F. - Video game localization: the case of Brazil

\begin{tabular}{|c|c|c|c|}
\hline \multicolumn{4}{|c|}{ Table 1} \\
\hline \multicolumn{2}{|c|}{ Armor/Armadura } & \multicolumn{2}{|c|}{ Boots/Botas } \\
\hline Wonder Boy & Mônica & Wonder Boy & Mônica \\
\hline Light Armor & Armadura Simples & Cloth Boots & Botas de Pano \\
\hline Heavy Armor & Armadura de Bronze & Leather Boots & Botas de Couro \\
\hline Knight Armor & Armadura Especial & Ceramic Boots & Botas Especiais \\
\hline Hard Armor & Armadura de Aço & Legend Boots & Botas Mágicas \\
\hline Legend Armor & Armadura Diamante & Wing Boots & Botas Voadoras \\
\hline \multicolumn{2}{|c|}{ Shields/Escudos } & \multicolumn{2}{|c|}{$\begin{array}{c}\text { Weapons \& Magic Spells/Armas \& } \\
\text { Magias }\end{array}$} \\
\hline Wonder Boy & Mônica & Wonder Boy & Mônica \\
\hline Light Shield & Escudo Simples & Bombs & Bombas de Limpeza \\
\hline Knight Shield & Escudo de Ferro & Tornado & Rodamoinho Mágico \\
\hline Hard Shield & Escudo de Aço & Fire Ball & Detergente \\
\hline Legend Shield & Escudo Diamante & Thunder Flash & Raio Limpo \\
\hline
\end{tabular}

It is possible to observe that the English version privileges the use of military terms, which approximates Wonder Boy to the Ancient and Middle Ages, insofar as the name of many items derive from those used by the armies of those times, especially for armor and shields. In the Portuguese version, the terms are related to a more imaginary world, which is justifiable given that Mônica's stories are directed to children. It becomes evident when we compare some of the terms. For example, the term Light Armor became Armadura Simples ("Simple Armor") in the Portuguese version. Light Armor is a very specific term, used to identify the kind of armor worn by a light infantryman. The same applies to Heavy Armor and Knight Armor, which refers to the equipment utilized by soldiers belonging to the heavy infantry and cavalry respectively. In the Portuguese version, these terms were "neutralized", giving preference to the kind of material with which the equipment was made, as is the case of Armadura de Bronze ("Bronze Armor"), Armadura de Aço ("Steel Armor"), Escudo de Ferro ("Iron Shield") and Escudo 
Souza, R. V. F. - Video game localization: the case of Brazil

de Aço ("Steel Shield"). In contrast, there are various terms in the Portuguese version that suggest a world of magic and dreams, commonly seen in fantasy literature. As an example, we can take the terms Ceramic Boots and Legend Boots. In the former case, it was chosen not to translate it literally, changing Botas de Cerâmica into Botas Especiais ("Special Boots"). The substitution of the English word Ceramic by the Portuguese word Especial gave a more abstract sense to the boots, which can also be linked to the world of fantasy. The same occurs with regard to Legend Boots. Although the word Legend may refer to something imaginary, it may also refer to something or someone real. For example, one can say that Pelé is a soccer legend; we are not talking about an imaginary person but a real one. Thus, it was decided to replace Botas Lendárias (the equivalent in Portuguese of Legend Boots) by Botas Mágicas ("Magic Boots"), which suppressed any element of "reality", giving the term a more imaginary sense. Finally, let us focus on the weapons and magic spells. It is important to recall that Mônica's main antagonist in the game is Capitão Feio, a character who is marked by his relation to dirt and filth. For this reason, Mônica must have tools which are capable of countering his "dirty powers". This led to some sort of adaptation of the names of her weapons and magic spells, which were renamed so as to make them verisimilar to Mônica and Capitão Feio's stories. Therefore, Bombs became Bombas de Limpeza ("Cleanliness Bombs"), Fire Ball turned into Detergente ("Detergent"), and Thunder Flash was changed into Raio Limpo ("Clean Thunderbolt"). The only term that did not follow the pattern above is Tornado, which was translated as Rodamoinho Mágico ("Magic Whirlwind").

One last aspect about Mônica no Castelo do Dragão can be seen in the images below: 
Souza, R. V. F. - Video game localization: the case of Brazil

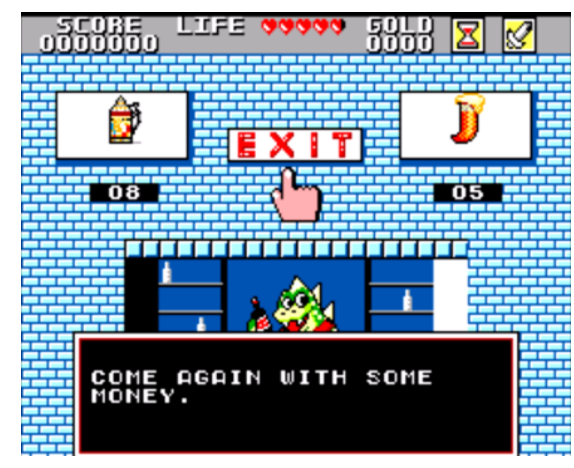

Image 10: One of the item shops in

Wonder Boy in Monster Land.

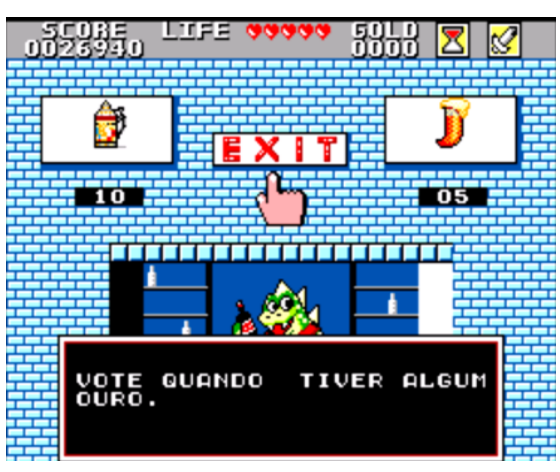

Image 11: One of the item shops in Mônica no Castelo do Dragão.

Although the game was very well translated, an important detail cannot go unnoticed: the absence of one letter can change the entire meaning of a sentence. As seen above, the sentence Come Again With Some Money was translated as Vote Quando Tiver Algum Ouro. The problem resides in the translation of the excerpt Come Again: the literal translation would be Venha Novamente, which was obviously rejected due to the excessive number of characters. The solution for this problem was to use the verb Voltar ("To Come Back") in its imperative form Volte. But the letter $L$ was not inserted in the word, turning Volte $\left[{ }^{\prime} \mathrm{Vowt} \mathrm{j}^{11}\right]$ into Vote $\left[{ }^{11} \mathrm{vot} \mathrm{j}^{12}\right]$. What occurs is that Vote is the imperative form of the verb Votar ("To Vote"). Hence, instead of Volte Quando Tiver Algum Ouro ("Come Back When You Have Some Gold") the sentence became Vote Quando Tiver Algum Ouro ("Vote When You Have Some Gold"). And, even though the context prevents any kind of misinterpretation (this sentence only appears when the player has no money to buy the items), this could have caused problems, since Vote Quando Tiver Algum Ouro could indicate some kind of obscure political relationship or something of that sort. Therefore, it is extremely important to be attentive to all the details that touch on the translation process, in order to prevent something like this from happening.

\footnotetext{
${ }^{11}$ Other possible realizations of the word "Volte" were not considered.

${ }^{12}$ Other possible realizations of the word "Vote" were not considered.
} 
Souza, R. V. F. - Video game localization: the case of Brazil

Even with all the problems and limitations, the early 1990's was the most productive period for video game localization in Brazil. Sega Master System and its successor Sega Genesis/Mega Drive were extremely successful in Brazil, although the latter had to compete with the Super Nintendo Entertainment System (SNES). And the next generation of consoles was on the verge of being released. There was great expectation and all the predictions were the most optimistic possible. However, as we all know, things change.

After Sony Playstation's release, the video game sector in Brazil went through an intense downturn, exposing two problems that have plagued the local market and which contributed decisively to its marginalization: piracy and the tax burden. Piracy has always been a problem in Brazil, but from the mid-1990's it grew enormously. With the transition from cartridges to CDs, the cost of manufacturing and large-scale production of pirated games fell dramatically, causing a boost in piracy and discouraging many companies from investing in Brazil. It even caused a curious situation: despite having never released Playstation officially in the country, Sony became the absolute leader in the Brazilian market. Due to the lack of the official products in the country, whoever wanted to buy the original console and/or games had to import them. However, for a game or console to be legally imported in Brazil, the importer had to pay an array of taxes, whose total could inflate the final price of a game by up to 80 percent, or, in the case of the consoles, by more than 100 percent (EDGE 2010). It obviously caused a serious damage to the Brazilian market, and, the consequences for video game localization were inevitable: the number of games localized into Brazilian Portuguese declined considerably, and finding them was not an easy task, especially in the consoles. Not all was lost, though. It can be said that PC games were the responsible for the "survival" of video game localization in Brazil. Even though piracy also affected them, the tax burden was somewhat lower than in the consoles, which allowed more competitive prices and reasonable sales numbers. For this reason, some multiplatform games had their PC versions localized into Portuguese and were officially marketed in Brazil. 
Souza, R. V. F. - Video game localization: the case of Brazil

\section{$\odot$ Max Payne (Remedy Entertainment /3DRealms/Gathering OF DEVELOPERS 2001)}

Distributed and marketed in Brazil by Greenleaf, Max Payne was released in Brazil in December, 2001, in a version fully adapted to the Brazilian audience. Due to the technological advances, Max Payne's process of localization may be considered a bit less "thorny" than Phantasy Star's. It already becomes evident when examining the installation menu:

\begin{tabular}{|l|l|}
\hline \multicolumn{2}{|c|}{ Table 2 } \\
\hline Installation Menu & Menu de Instalação \\
\hline Play & Jogar \\
Uninstall & Desinstalar \\
Re-install Max Payne & Re-instalar Max Payne \\
View Readme & Ver o Leia-me \\
Max-Fx Tools & Ferramentas Max-Fx \\
About & Sobre \\
Browse CD Contents & Pesquisar o Conteúdo do CD \\
Exit & Sair \\
\hline
\end{tabular}

Here, the menu is much more adjusted to the linguistic conventions of the Portuguese language, insofar as the prevalence of infinitive verbs denotes a much more natural way of reproducing a menu in Portuguese. The alphabet was also completely adapted to the reality of the language, enabling the use of all of its characters, even those which were absent in Phantasy Star. This is what allowed the term Options to be translated into its equivalent Opções [op'sõjs ${ }^{13}$ ], instead of the non-existent Opcoes [op'koes]. Another important aspect is that, when compared to past generations, space constraints became a bit more "generous". This "flexibility" made possible the employment of

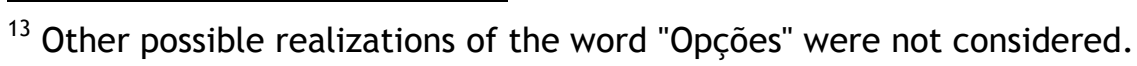


Souza, R. V. F. - Video game localization: the case of Brazil

more refined sentences, ensuring a greater fidelity to the original text. The main example in this regard is the sentence Browse CD Contents, translated as Pesquisar o Conteúdo do $C D$, construction which used twenty-six characters (with spaces), something unthinkable in previous generations and considered high even by modern standards.

With reference to the audiovisual content, both dubbing and subtitling were present in the game: in-game dialogues were dubbed, whereas the cutscenes (presented as parts of a graphic novel) were both dubbed and subtitled. The subtitling did not show changes in respect to the dubbing, serving as a faithful reproduction of what was being said. For its part, the dubbing of the in-game dialogues fulfills its role, with a special emphasis on the performance of the protagonist (carried out by Brazilian actor Mauro Castro). But one detail attracts attention: the constant use of the ênclise pronominal ("pronominal enclisis"), particularly in imperative affirmative sentences. Before analyzing the linguistic issues in the game, it is important to examine this aspect of the Portuguese language. The term ênclise pronominal is defined as:

The placement of the personal object pronoun after the verb (MICHAELIS 1998-2007).

Normative grammar says that it is incorrect to start a sentence with an object pronoun. In these situations, the use of the enclisis is required, inasmuch as the sentences must always obey the sequence "Verb + Object Pronoun". Thus, constructions like Tell me are supposed to be translated as Diz(e)-me/Diga-me instead of Me diz/Me diga. Normative grammar also establishes that a verb in its imperative form must never be followed by a subject pronoun. For this reason, constructions like Pega-o/Pegue-o ("Get him") would be considered perfect examples of the application of this rule, whereas Pega ele/Pegue ele (literally "Get he") would be considered ungrammatical. But grammar is not the only element that constitutes a language; usage (particularly in speech) is another important factor that 
Souza, R. V. F. - Video game localization: the case of Brazil

cannot be disregarded. In speech, the use of the above rules is different in the European and Brazilian variants of Portuguese: the former tends to follow these rules, privileging the use of the enclisis and the use of object pronouns after imperative verbs, whereas the latter prefers the proclisis (object pronouns placed before the verbs) and the use of subject pronouns after imperative verbs. While the constructions Me diz/Me diga and Pega ele/Pegue ele might sound odd and incorrect in Portugal, they are common in Brazil. And although normative grammar is usually respected in formal writing, it is quite rare to observe it in the everyday speech in Brazilian Portuguese, even among educated speakers. Thus, it can be said that there are two distinct educated standards in Brazilian Portuguese: an educated written standard, which must strictly follow the normative grammar, and an educated spoken standard, more informal, flexible and dynamic than the written standard.

That said, let us now go over the linguistic issues observed in the game. Throughout the game, Max Payne tries to find out everything he can about a new drug called Valkyr. During his investigations, he runs into a large number of enemies, who will do what they can to stop him. When they notice Max Payne's presence, they utter sentences like Mate-o ("Kill him"), Acerte-o ("Hit him"), Pegue-o ("Get him"), and Derrube-o ("Knock him down"). These sentences are totally in accordance with normative grammar. However, the use of the enclisis is more common in written language, being rarely seen in spoken language. Consequently, its use would be more appropriate in subtitling, since it is the audiovisual resource which usually follows the educated written standard. As they were used in the dubbing, the above sentences were perfectly comprehensible, but they sounded too formal for the spoken language. Another interesting point is that, regardless of the large use of the enclisis throughout the game, some "proclitic islands" can be observed amid the vast "enclitic sea". It can be seen more clearly in the prologue of Chapter III: A Bit Closer To Heaven, wherein Max Payne gets beaten and injected with an overdose of Valkyr by a group of enemies under the orders of Nicole Horne, president of Aesir (the company responsible for 
Souza, R. V. F. - Video game localization: the case of Brazil

the production of the drug). The cutscene is divided in three illustrations, placed in chronological order from the left to the right. The sentences below belong to the first and second illustrations:

Table 3

First Illustration: Nicole Horne, right after her henchman applied the overdose on Max Payne

English: Gentleman, we are done here. Take me to Cold Steel.

Portuguese: Cavalheiros, terminamos aqui. Levem-me para Cold Steel.

\begin{tabular}{|l|}
\hline \multicolumn{1}{|c|}{ Table 4} \\
\hline $\begin{array}{l}\text { Second Illustration: Max Payne describing the effects that Valkyr was having on } \\
\text { him }\end{array}$ \\
$\begin{array}{ll}\text { English: } & \begin{array}{l}\text { They turned to steam. They did a fade on me. I had never had a } \\
\text { chance. } \\
\text { Eles se transformaram em vapor. Me apagaram. Em nenhum } \\
\text { Portuguese: }\end{array} \\
\text { momento tive chance }\end{array}$ \\
\hline
\end{tabular}

In the first illustration, the expression Take me was translated as Levem-me, in total conformity with normative grammar. Although the proclisis is more used in spoken language, the use of the enclisis follows the pattern adopted during the entire game. On the other hand, the second illustration shows exactly the opposite: They did a fade on me was translated as Me apagaram (literally "Blacked me out"), countering everything that had been done thus far. In this case, the use of the proclisis is "forbidden" by normative grammar, which indicates two options to solve the "problem": a.) to include a subject pronoun in the beginning of the sentence, changing Me apagaram into Eles me apagaram, in which Eles is the equivalent in Portuguese of They; b.) to use the enclitic construction Apagaram-me. Eles me apagaram would sound a little strange, for the subject pronoun Eles might give an idea that a group of people (and not the agents of the drug) were the 
Souza, R. V. F. - Video game localization: the case of Brazil

responsible for him to lose consciousness. And if the context points to a group of people as the perpetrators of the action, the meaning of the sentence would also change, given that, aside from the idea of "To Lose Consciousness", the verb Apagar (particularly if preceded by a subject pronoun) may also mean "To Kill" in colloquial Brazilian Portuguese. As for the enclisis, its use would be more comprehensible, not as it is the best option, but as a matter of textual coherence: even though the use of the proclisis makes the sentence more natural, the enclisis was used during the entire game, resulting in its use in this case to be more coherent to the whole.

One last aspect to consider regards the presence of in-game graphic arts. In Max Payne's localization process, it was decided not to translate (except during the cutscenes) the linguistic elements present in in-game signs, posters, drawings, etc. Considering that the game takes place in New York City, this was a correct decision, since all the environment of the city was preserved: not only is the city cited during the entire game, but other elements like the incessant snow and the harsh winter give a quite different sense of reality from that of living in Brazil, where most people live in a warm climate. Even so, the translator must always be attentive to one question: can the lack of translation affect gameplay? In Max Payne's case, in ninety-nine percent of the game it did not. In one section of the game, though, it might cause some problems. In Part II: A Cold Day in Hell, Chapter II: An Offer You Can't Refuse, Max Payne is in search of the cargo ship Charon. During the mission, he comes across a drawbridge, which had been lifted by the enemies to block his way through. When looking for an alternative route, he finds a fence (also blocking his way) and a truck parked on the other side. That is when the problem comes up. Apparently blocked on all sides, the player starts going back and forth in search for alternatives on how to overcome this hurdle. After some time without finding any solution, he/she feels stuck and does not know what to do. More attentive players will probably notice the existence of a poster near the fence, which supposedly provides the necessary instructions to go on. The poster displays the sentence Caution! Use wheel 
Souza, R. V. F. - Video game localization: the case of Brazil

blocks when parking in this area. Right below it, there is a drawing of a wheel block protecting the truck from moving. At first glance, the non-translation of the message does not make much difference, insofar as the drawing solves all the problems, by showing the player that he/she has to shoot the wheel block in order to cause the truck to move and unblock the passage near the drawbridge. However, the simple fact that the message in the poster is in a foreign language makes most players ignore it and turn their attention to solving their most urgent problem, which is to find a way through; and as they cannot, they get really frustrated. Here, the interference that the nontranslation causes in gameplay is evident. It is true that keeping the sentences in English was a correct decision to recreate the environment of New York City. But, in this specific case, the translation of this poster could have avoided the annoyance many players eventually had.

The aforementioned issues did not take the shine away from the Portuguese version of Max Payne; on the contrary, the game is regarded by many as the best localized game ever to be sold in Brazil. Nonetheless, the game was just a sporadic attempt amid the unfortunate reality experienced by the Brazilian market during those years. Notwithstanding, new winds would blow and start changing once again the course of video games in Brazil.

The 2000's (in particular the second half of the decade) saw great changes in Brazil. With the economic growth and the consequent increase in the purchasing power of Brazilians, the country began to position itself on the international scene as an emerging superpower, which aroused the interest of many foreign companies that viewed Brazil as a potential market with great prospects for expansion. The video game market was no different: despite all the problems described in the previous paragraph, the local market was reinvigorated by the official arrival of many video game giants like Microsoft, Sony, Ubisoft, Blizzard among others, all of which officially released their consoles and/or games in Brazil. As a result, the impact on video game localization was considerable, with the gradual growth in the number of games localized into Brazilian Portuguese. Another important point is that 
Souza, R. V. F. - Video game localization: the case of Brazil

since Level Up released a localized version of Ragnarök Online (GRAVITY 2002) in 2004, an increasing number of $M M O^{14}$ games have been appearing in Brazil in completely localized versions in Brazilian Portuguese and directed to the needs of the local audience. This demonstrates that, even with all the difficulties, the video game sector is slowly getting back on track, revealing all its potential and capability of returning to its days of glory and becoming consolidated as one of the key markets in the video game industry.

\section{○ Pro Evolution Soccer 2009 (KONAMI 2008)}

As it is a simulator of the most popular sport in Brazil, Pro Evolution Soccer is one of the best loved series with Brazilian gamers, which has certainly contributed to make it one of the top selling games in the country. In this regard, Pro Evolution Soccer 2009 (commonly abbreviated as PES 2009) is of fundamental importance as it is the first edition of the game to offer Portuguese (European) as one of the languages available, along with English, French and Spanish. But, perhaps due to the fact that it was being used for the first time, the Portuguese version had some important differences in relation to the other three languages.

A first point to be observed is that the Portuguese version received just a partial localization. Unlike the English, French and Spanish versions, where both in-game texts and audio were localized, the Portuguese version only featured the translation of the former. Any player wanting to play the game in Portuguese would have to be contented with just the in-game texts; the audio would have obligatorily to be in English, French or Spanish. The partial localization also affected the names of the countries. For some unknown reason, they were not translated, not only into Portuguese, but neither into Spanish or French. In an exhibition game between Germany and Switzerland, for example, the screen will always display the English terms Germany and Switzerland, regardless of the language that the player has selected. This

\footnotetext{
${ }^{14}$ Massive Multiplayer Online.
} 
Souza, R. V. F. - Video game localization: the case of Brazil

ends up being frustrating, seeing that when the player chooses to play the game in one language, he/she expects to enjoy everything the game has to offer in that language. The impossibility of doing so will possibly decrease the level of identification the player can create with the game, causing a sensation of "incompleteness". As a result, gameplay experience will be fatally compromised, for not entirely conveying in the localized version the same experience as the original.

On the other hand, the absence of the audio made the translation process much simpler. Although the European variant was taken as a reference, the fact that it was basically an orthographic translation made, in a way, the version very accessible for both Brazilian and Portuguese audiences. Even though some lexical choices may sound somewhat strange to Brazilians - as is the case of the word Ecrã ("Screen"), whose equivalent in Brazil is Tela -, the translation as a whole was very clear and objective, regardless of the variant. By looking at the main menu, this becomes evident:

\begin{tabular}{|l|l|l|l|}
\hline \multicolumn{3}{|c|}{ Table 5 } \\
\hline \multicolumn{3}{|c|}{ Main Menu } \\
English & Portuguese & French & Spanish \\
Uefa Champions League & Uefa Champions & Uefa Champions & Uefa Champions \\
Exhibition & League & League & League \\
Become a Legend & Exhibition & Exhibition & Exhibición \\
Master League & Rumo ao & Vers une Légende & Ser uma Leyenda \\
League - Cup & Estrelato & Ligue des Masters & Liga Master \\
Network & Liga Master & Ligue - Coupe & Liga - Copa \\
Legend & Liga - Taça & Réseau & Red \\
Messages & Network & Légendes & Leyendas \\
Training & Estrelas & Messages & Mensajes \\
Edit & Mensagens & Entrainement & Entrenamiento \\
Gallery & Treinos & Modifier & Editar \\
System Settings & Editar & Mode Galerie & Galería \\
Galeria & Refinições de & Ajuges Systéme & Ajuste de Sistema \\
& Sistema & & \\
\hline
\end{tabular}


Souza, R. V. F. - Video game localization: the case of Brazil

From the twelve terms from the Main Menu, eight were fully translated into Portuguese, one was partially translated (Master League became Liga Master), whereas the three remaining options (Uefa Champions League, Exhibition and Network) were not changed. With respect to the partial translation, the term Master League has been in use in the series for many years, and players all around the world are already very familiar with it. A full translation, something like Liga Mestre or Liga Mestra, would mischaracterize it, by replacing a term long known by any fan of the game by another which has no affective appeal. For this reason, two possible options emerged as solution for the problem: either maintain the already established term Master League or perform a partial translation. In this case, the second option was chosen: the word League was replaced by its equivalent in Portuguese Liga, while the term Master, which could retain some kind of affective bond with the original term, remained untouched. Next, we have three non-translated terms: Uefa Champions League, Exhibition and Network. In the former case, although the term is already quite widespread throughout the world, it could perfectly be translated as Liga dos Campeões da Uefa, since it is a term widely known and used in both Brazil and Portugal. The probable reason for the non-translation is that Uefa Champions League is the official name of the competition, and, as such, should not be translated. As for Network and Exhibition, even though their equivalents in Portuguese, Rede and Exibição, are not the most suitable options, the reason for which they were not translated is unknown, especially when considering that these terms received their respective translations into French and Spanish. Hence, while the menus in the French and Spanish were fully translated (except for Uefa Champions League as mentioned), it can be said that the Portuguese version received a "bilingual translation". In general, the translation is competent, with recognizable terms for both Brazilian and Portuguese players, since many of the terms utilized are common to both variants of the language. The only "differences" reside in the words Taça and Definições, whose equivalent and 
Souza, R. V. F. - Video game localization: the case of Brazil

more used terms in Brazil are Copa and Configurações. But this is not a difference that can interfere in the comprehension of the term, since every Brazilian knows the meanings of Taça and Definições; it is more of a matter of habit and usage.

One final aspect does not involve any linguistic issue, but very clearly demonstrates the concept of "to make local", essential for a successful localization. In the case of soccer simulators, this conceptual approach can be made by offering the local teams among the options to be selected. For the Portuguese audience, this approach was partially realized: although the Portuguese League was not licensed, the three most popular teams in the country (SL Benfica, FC Porto and Sporting CP) were available. Thus, many of the Portuguese players were able to play the game with their favorite teams. The same cannot be said of the Brazilian audience: only SC Internacional was available in the game. And in spite of the fact that SC Internacional is an important team, Brazil has eleven other giants: C Atlético Mineiro, Botafogo $F R$, SC Corinthians $P$, Cruzeiro EC, CR Flamengo, Fluminense FC, Grêmio FBPA, SE Palmeiras, Santos FC, São Paulo FC and CR Vasco da Gama. Thus, most Brazilian players were not able to play the game with their favorite teams, having to resort to the Edit Mode to create them. This turned out to be somewhat annoying due to the excessive time spent to create the teams; it is not uncommon to hear from players that they spent more time editing the teams than actually playing the game. This definitely compromises gameplay: instead of creating a fun experience, it delivers a quite tiring one.

All in all, the presence of the Portuguese language in a series the caliber of Pro Evolution Soccer is laudable. Problems like the aforementioned may cause some nuisance for some players, but the presence of the language is important to give the opportunity for these problems to be corrected. And that is what happened: in PES 2010, both in-game texts and comments were fully localized into Portuguese (European); PES 2011 features comments in both European and Brazilian Portuguese (made by Pedro Sousa and Luis Freitas Lobo in the former and by Silvio Luiz and Mauro Beting in the latter), whereas 
Souza, R. V. F. - Video game localization: the case of Brazil

four teams from Portugal (SL Benfica, SC Braga, FC Porto and Sporting CP) and the five Brazilian teams present in the 2010 Copa Santander Libertadores (SC Corinthians P, Cruzeiro EC, CR Flamengo, SC Internacional and São Paulo $F C$ ) were present in the game. Finally, in addition to once again featuring comments in both variants of the language, PES 2012 (on the verge of being released in Brazil at the time of writing) will bring back the six Brazilian teams in the 2011 Copa Santander Libertadores (SC Corinthians P, Cruzeiro $E C$, Fluminense FC, Grêmio FBPA, SC Internacional and Santos FC) and, for the first time in the franchise, the Portuguese League will appear in the game, although partially licensed ${ }^{15}$.

\section{Perspectives}

Perspectives for the future of video games in Brazil could not be brighter. Each day, more and more companies start their business operations in the country, opening a new range of opportunities not only for the development of the local market but also for video game localization. Games like Halo: Reach (Microsoft/Bungie 2010), Killzone 3 (SONY/GUeRRILLA 2011), Mortal Kombat (WARner Bros/NetherRealm 2011), Infamous 2 (SONY/SUCKER PUNCH 2011) and Gears of War (Microsoft/Epic Games, 2011) were recently released in versions localized into Brazilian Portuguese ${ }^{16}$. Also, at the time of writing, the upcoming games Assassins Creed Revelations (UBISOFT), Batman: Arkham City (WARNER BROS/ROCKSTEADY), World of Warcraft (BLIZZARD) and Uncharted 3: Drake's Deception (Sony/Naughty Dog) are also set to offer Portuguese as one of the languages available ${ }^{17}$. Moreover, there is the project

\footnotetext{
${ }^{15}$ Only SL Benfica, FC Porto and Sporting CP will be fully licensed; the remaining teams will appear with fictitious names.

${ }^{16}$ Halo: Reach, Killzone 3 and Infamous 2 were both dubbed and subtitled; Mortal Kombat and Gears of War 3 were only subtitled.

${ }^{17}$ World of Warcraft and Uncharted 3: Drake's Deception will be both dubbed and subtitled; Assassins Creed Revelations and Batman: Arkham City will be only subtitled.
} 
Souza, R. V. F. - Video game localization: the case of Brazil

Jogo Justo (FAIR GAME), which aims at showing the government all the benefits that a tax reduction on video games can bring to the Brazilian economy, not only for increased tax revenues or job creation, but also as a strategy to combat piracy. Finally, on September 27th, 2011, two more good pieces of news: Microsoft officially announced the manufacturing of its Xbox 360 in Brazil (AZEVEDo 2011), thereby allowing a significant reduction in its prices and, at the same time, offering potential consumers the perspective of greater access to the console in the country; on the same day, the Executive Secretary of the Ministry of Science, Technology and Innovation, Luis Antonio Rodrigues Elias, stated that the other two giants, Sony and Nintendo, are both negotiating with the Government in order to also manufacture their consoles in Brazil (UOL Jogos 2011); however, at the time of writing, there has still been no official confirmation by both companies on the subject. In view of all this, it can be said that Brazil has what it takes to become a superpower, not only in the international scene, but also in the magical world of video games.

\section{References}

ACTIVE GAMING MEDIA (2010). History of Game Localization

http://www.activegamingmedia.com/news/history-of-game-localization < Last accessed on April 15 ${ }^{\text {th }}, 2011>$.

AzEvedo, T. (2011). Microsoft oficializa produção do Xbox 360 no Brasil; console chega em 5 de outubro por R\$ 800. In: UOL Jogos, September $27^{\text {th }}, 2011$.

http://jogos.uol.com.br/ultimas-noticias/2011/09/27/microsoft-oficializafabricacao-do-xbox-360-no-brasil.htm <Last accessed on September 27th>.

Barton, M \& Loguidice, B (2009). The History Of Pong: Avoid Missing Game to Start Industry.

http://www.gamasutra.com/view/feature/3900/the_history_of_pong_avoid_ missing_.php $<$ Last accessed on March 11 ${ }^{\text {th }}$, 2011>. 
Souza, R. V. F. - Video game localization: the case of Brazil

. (2009). The History of Spacewar!: The Best Waste of Time in the History of the Universe. http://www.gamasutra.com/view/feature/4047/the_history_of_spac ewar_the_best_.php .

$<$ Last accessed on March $13^{\text {th }}$, 2011>

Bernal Merino, M. (2006). On the Translation of Video Games. The Journal of Specialised Translation 6, 22-36. http://www.jostrans.org/issue06/art_bernal.pdf <Last accessed on September $27^{\text {th }}$, 2011>.

Bernal Merino, M. (2007). Challenges in the Translation of Video Games. Tradumàtica 5.

http://ddd.uab.cat/pub/tradumatica/15787559n5a2.pdf < Last accessed on September $27^{\text {th }}$, 2011>.

DieTZ, F. (2007). How Difficult Can That Be - The Work of Computer and Video Game Localization. Tradumàtica 5.

http://ddd.uab.cat/pub/tradumatica/15787559n5a4.pdf <Last accessed on May $11^{\text {th }}, 2011>$.

Discovery Channel Brasil (2007). a Era do Videogame.

Edge Magazine (2010). Diversão Acessível. Editora Europa: Issue 15 (August, 2010), p.11.

ESA (2011). Essential Facts About The Computer and Video Game Industry

http://www.theesa.com/facts/pdfs/ESA_EF_2011.pdf <Last accessed on September $27^{\text {th }}$, 2011>.

"GaGÁ" RoB, O. (2009). Phantasy Star Eterno. In: Old!Gamer Magazine. Editora Europa: Issue 2 (November, 2009), p.16-37.

Lambert, B. (2008). Brookhaven Honors a Pioneer Video Game. In: New York Times

(United

http://www.nytimes.com/2008/11/09/nyregion/longisland/09videoli.html <Last accessed on March 12 ${ }^{\text {th }}, 2011>$.

MANGIRON, C. \& O'HAGAN, M. (2006). Game Localisation: Unleashing Imagination with 'Restricted' Translation. The Journal of Specialised Translation 6, p.1021.

http://www.jostrans.org/issue06/art_ohagan.pdf <Last accessed on September $27^{\text {th }}$, 2011>.

Michaelis (1998-2007). Moderno Dicionário da Língua Portuguesa (Online version). Editora Melhoramentos. http://michaelis.uol.com.br/moderno/portugues/index.php_<Last accessed on September 27th, 2011>.

Nowak, P. (2008). Video games turn 50. In: CBC News (Canada) 
Souza, R. V. F. - Video game localization: the case of Brazil

http://www.cbc.ca/news/technology/story/2008/10/15/tech-games.html $<$ Last accessed on March, $8^{\text {th }}, 2011>$.

O'HAGAN, M. (2007). Video games as a new domain for translation research: from translating text to translating experience. Tradumàtica 5.

http://ddd.uab.cat/pub/tradumatica/15787559n5a9.pdf < Last accessed on May $12^{\text {th }}, 2011>$.

SCHOLAND, M. (2002). Localización de Videojuegos. Tradumàtica 1

http://www.fti.uab.es/tradumatica/revista/articles/mscholand/mscholand.P DF <Last accessed on May 11 ${ }^{\text {th }}$, 2011>.

SUZUKI, A. (2009). Master System completa 20 anos de vida no Brasil. In: UOL Jogos, September $4^{\text {th }}, 2009$.

http://jogos.uol.com.br/ultnot/multi/2009/09/04/ult530u7180.jhtm <Last accessed on April $7^{\text {th }}, 2011>$.

UOL JoGOS (2009). Japoneses reclamam de dublagem de Modern Warfare 2

http://jogos.uol.com.br/ultnot/multi/2009/12/06/ult530u7440.jhtm <Last accessed on September 4th, 2011>.

UOL JoGos (2010). Indústria de jogos moverá US\$ 65 bilhões em 2013

http://jogos.uol.com.br/xbox360/ultnot/2010/02/23/ult3277u27070.jhtm $<$ Last accessed on April 28 ${ }^{\text {th }}, 2011>$.

UOL Jogos (2011). Sony e Nintendo negociam para fabricar no Brasil, diz Governo.

http:/ / jogos.uol.com.br/ultimas-noticias/2011/09/27/sony-e-nintendonegociam-para-fabricar-no-brasil-diz-governo.htm <Last accessed on September, $27^{\text {th }}, 2011>$.

\section{Games}

Call of Duty: Modern Warfare 2 (United States, 2009). ActivisION/INFINITY WARD: Playstation 3/ Xbox 360/ PC (Windows).

DONKEY KONG (Japan, 1981). Nintendo: Arcades.

Fifa INTERNATIONAL SOCCER (United States, 1993). EleCtronic ARTS: Genesis/Mega Drive.

Final Fantasy VII (Japan, 1997). SQUARE (now Square Enix): Playstation.

Gears of WAR (United States, 2011). Microsoft/EPIC Games: Xbox 360. 
Souza, R. V. F. - Video game localization: the case of Brazil

GHOST 'N GOBLINS (Japan, 1986). CAPCOM: Nintendo Entertainment System (NES). Halo: Reach (United States, 2010). Microsoft Game Studios/Bungie: Xbox 360. INFAMOUS 2 (United States, 2011). SONY/SUCKER PUNCH: Playstation 3.

Killzone 3 (United States, 2011). Sony Computer Entertainment/Guerrilla Games: Playstation 3.

MaX Payne (United States, 2001). Remedy EntertaInMent /3DREalms/GatheRING OF DEVELOPERS: PC (Windows).

Metal Gear Solid (Japan, 1998). Konaml: Playstation .

Metal Gear Solid 3: SNAKE EATER (Japan, 2004). Konami: Playstation 2.

MORTAL KOMBAT (United States, 2011). WARNER BROS. INTERACTIVE ENTERTAINMENT/NetherRealm Studios: Playstation 3/ Xbox 360.

Mônica no Castelo do Dragão (Brazil, 1991). TeC ToY: Master System.

PAC-MAN (Japan, 1980). NAMCO: Arcades.

Phantasy StaR (Japan, 1987). Sega: Master System.

PONG (United States, 1972). ATARI: Arcades.

Pro EVolution SOCCER 2009 (United States, 2008). Konaml: Playstation 3/ Xbox 360/ Wii/ PSP/ Playstation 2/ PC (Windows)/ Mobile.

PRo Wrestling (Japan, 1986). Nintendo: Nintendo Entertainment System (NES).

RAGNARÖK ONLINE (Korea, 2002). GRAVITY: PC (Windows).

RESIDENT EVIL (Japan, 1996). CAPCOM: Playstation.

SPACEWAR! (United States, 1962). STeVe Russell: PDP1 Computer.

SPACE INVADERS (Japan, 1978). TAITO: Arcades.

STARCRAFT II: WINGS OF LIBERTY (United States, 2010). BLIZZARD: PC (Windows/ MaC OS X).

SUPER MARIO BROS. (Japan, 1985). NINTENDO: Nintendo Entertainment System (NES).

TENNIS FOR Two (United States, 1958). William A. Higinbotham: Analog Computer/ Oscilloscope.

WONDER BOY IN MONSTER LAND (United States, 1988). SeGA: Master System. 